\title{
The Growth Rates of Major Academic Libraries: Rider and Purdue Reviewed
}

In The Scholar and the Future of the Research Library Fremont Rider hypothesized that since in the past academic libraries have doubled in size every sixteen years, this rate of growth can be expected to continue through the immediate future; he invoked this hypothesis to demonstrate the scope of the problem that such growth will engender. The 1965 Purdue study of library growth in a sense verified Rider's hypothesis and its use as a predictive tool. This study, which measures the growth rates of the twenty-five largest ARL libraries from 1962-63 through 1973-74, discredits the validity of Rider's hypothesis, notes the limitations of the Purdue study growthrate figures, and tentatively identifies the collection size level past which growth-rate deceleration begins.

\section{$\mathrm{T}$}

HE PURPOSE OF THIS PAPER IS THREEFolD: (1) to review critically Fremont Rider's hypothesis about the exponential growth of research library collections as well as the growth-rate projections of the Purdue study; (2) to report and interpret the results of a study which measured the growth rates of the twenty-five largest Association of Research Libraries (ARL) libraries from 1963 through 1974; and (3) to determine if the resultant growth-rate figures corroborate the Rider hypothesis. ${ }^{1}$

\section{RIDER'S HYPOTHESIS ABOUT \\ FUtURE LIBRARY GROWTH}

Fremont Rider began the text of his book The Scholar and the Future of the Research Library by announcing that "although it had been known for a long

Steven Leach is information services librarian, Technological Institute Library, Northwestern University, Evanston, Illinois. time that American research libraries were growing at a very rapid rate, it was not realized until a few years ago that they were, on the average, actually doubling in size every sixteen years." 2 This opening statement summarized Rider's interpretation of the results of his study, which had measured the past rates of growth experienced by the categories of libraries shown in Table 1 .

The significance of exponential li-

TABLE 1

RIDER'S StUdy: LIBRARY CATEgORIES AND GROWTH Rates

\begin{tabular}{|c|c|}
\hline $\begin{array}{l}\text { Number of Libraries } \\
\text { per Category }\end{array}$ & $\begin{array}{l}\text { Average Doubling Period, } \\
1831-1938\end{array}$ \\
\hline $\begin{aligned} 10 & \text { Men's Colleges } \\
5 & \text { Women's Colleges } \\
10 & \text { Pre-1849 Universities } \\
10 & \text { Post-1849 Universities }\end{aligned}$ & $\begin{array}{l}22 \text { years } \\
16 \text { years } \\
9.5 \text { years }{ }^{\dagger}\end{array}$ \\
\hline
\end{tabular}

- Unspecified, but " $a$ more rapid growth than the men's colleges" (p.5). $\dagger$ 1876-1938

Source: Rider, The Scholar and the Future of the Research Library, p.4-8. 
brary growth to the future efficacy of the university library was not lost upon Fremont Rider:

In fact, this may be asserted as almost axiomatic: unless a college or university is willing to be stagnant, unless it is willing not to maintain its place in the steady flow of educational development, it has to double its library in size every sixteen years, or thereabouts. $^{3}$

Here, Rider appropriated the truism that there exists a direct correlation between continuous library growth and the educational effectiveness of any university, combined it with his conclusion about the past rate of library growth, and thereby constructed a seemingly incontestable argument from which he extrapolated his hypothesis about the rate of future library growth.

Rider then proceeded to demonstrate that the hypothesis reliably could be used to project library growth. However, his demonstration rested upon a rather tenuous argument consisting of (1) a reiteration of his preliminary argument; (2) a rhetorical sleight of hand; and (3) the following rationale: If the observed rate of library growth has prevailed for the past 200 years as is the case with Harvard and Yale, then in all probability that same rate of growth will prevail for the next 100 years. ${ }^{4}$ Moreover, Rider neglected to test the truth of his hypothesis by expanding his original study to include more libraries. In his review of Rider's book, Keyes D. Metcalf called attention to the omission of evidence which tended to discredit Rider's hypothesis:

If Mr. Rider had checked the reports of the New York Public Library and of the Harvard and Yale college libraries .... thirty-two years ago ... he would have found that they have failed to quadruple since that time and that their rate of growth on the percentage basis has been steadily de- creasing. If he had checked the "Gerould statistics" for libraries that had passed the five hundred thousandvolume mark sixteen years ago, he might have modified his figures, because he would have seen that, as libraries of any type grow larger, they tend to grow less rapidly. ${ }^{5}$

Needless to say, the rate of library growth as specified by Rider's hypothesis cannot be sustained indefinitely by any university library. Rider too conceded that "doubling every sixteen years" cannot "continue indefinitely" but qualified his concession by maintaining that in "so far as the foreseeable future is concerned" a deceleration in the rate of library growth was only "remotely probable." ${ }^{\prime}$ Even with his qualified acknowledgment, Rider did not impose any practical restrictions upon his use of the hypothesis to forecast levels of library growth.

In his review of the factors that in the future either would retard or stimulate library growth, e.g., new subject disciplines, the general level of education, etc., Rider did not discern that the diseconomies of large scale affect large university libraries as well as large corporations. $^{7}$ To elaborate, in time the continuous expansion of a library's collection at a $\mathrm{N}$-percent rate of growth will give rise to the diseconomies of large scale, whereupon that $\mathrm{N}$-percent rate of growth will become increasingly difficult to maintain because of the size of the collection. Certainly, Metcalf recognized that eventuality when he took exception to Rider's hypothesis and noted that "as libraries of any type grow larger, they tend to grow less rapidly."8

Moreover, in his analysis of the growth statistics, Rider did not assess the context in which past library growth had occurred. An extended evaluation of those factors, e.g., economic, mathematic, social, etc., which had affected past library growth admittedly would 
have gone beyond the purview of his study. Nevertheless, the author did not even indicate recognizance of any such relationships. Instead, Rider represented the growth of university libraries as being an isolated phenomenon. Given the incompleteness of his analysis, it is understandable why Rider failed to impose any practical restrictions upon his use of the hypothesis to predict library growth. Furthermore, it must be allowed that Rider was not specifically concerned about demonstrating the le fitimacy of his hypothesis, for in his to Metcalf's review Rider insisted:

This seems to me the vitally significan point-that, even though their [i.e., libraries'] rate of increase should shrink to doubling-every-twenty-years-or every thirty, or every forty years-the growth figures would still be so "astronomical" that the practical problems posed by them would be staggering ones. ${ }^{9}$

Rider was interested in demonstrating the validity of the hypothesis only insofar as the hypothesis was useful in demonstrating to the profession the reality of the library growth problem. One purpose of the book was to alert the library profession to the consequences of continuous exponential library growth. To that end, Rider used the hypothesis to dramatize the seriousness and the scope of that problem and to underscore his warning that the "problem of research library growth is, whether they realize it or not, by all odds the most serious one that librarians and educators face."10

Another purpose of the book was to publicize Rider's proposed solution to the growth problem, i.e., the extensive use of microtext. Although in most of the contemporaneous reviews of the book, attention primarily was focused on Rider's solution to the growth problem, ironically it was Rider's use of the hypothesis to predict library growth that since has become part of the professional litany to be cited whenever the growth of university libraries is discussed. This has occurred even though two papers were published in the early 1960s which tentatively concluded that the growth of the twenty-five largest university libraries from 1946 through 1960 had not substantiated Rider's hypothesis. ${ }^{11}$

\section{The Purdue Study}

For the previously cited 1965 Purdue study, all available statistics from 1950 51 through 1963-64 for fifty-eight ARL fibraries were examined. The derived growth-rate figures in turn were used to project library growth through 1980 . Initially, a composite library was created out of these statistics; however, because of the distortion caused by the presence of a few extremely large libraries, other composite libraries were created by assigning the fifty-eight libraries in the study to four different categories of collection size. The size categories and the corresponding growth figures are presented in Table $2 .{ }^{12}$

TABLE 2

Purdue Study: Library Categontes aNd Growth Rates

\begin{tabular}{lc}
\hline \hline \multicolumn{1}{c}{$\begin{array}{c}\text { Category } \\
\text { Name }\end{array}$} & $\begin{array}{c}\text { Approximate Doubling } \\
\text { Period }\end{array}$ \\
\hline Composite Library & 17 Years \\
Large Library & $18-20$ Years \\
Medium-Large Library & $12-14$ Years \\
Medium-Small Library & $12-14$ Years \\
Small Library & $14-16$ Years \\
\hline
\end{tabular}

Source: Dunn, Past and Likely Future, 1965, p.21, 37, $40,43,46$.

These figures seem to substantiate the accuracy of Rider's hypothesis to predict library growth. Similarly, in his review of the study, Guy Garrison observed that "the chief impression the reader gains from an examination of the report is that Fremont Rider was, in general, correct in his ominous predictions." ${ }^{13}$ Robert L. Talmadge remarked in his review that "this absorb- 
ing work might well have been dedicated to the late Fremont Rider," for, according to Talmadge, the growth rate computed for the fourteen largest libraries did not constitute "essential undermining of Rider's thesis." 14

Yet, in contrast to the derivation and utilization of the Rider hypothesis, the Purdue composite growth projections were developed from a more elaborate study of past library growth, were the product of a more sophisticated methodology, and were to be used in conjunction with such growth-related projections as volumes added, staff size, and book expenditures. Furthermore, as "an outgrowth of past studies" which had "proved helpful in developing plans for future growth," the Purdue growth projections specifically were intended to be used in that capacity, whereas no such application of Rider's hypothesis to library planning had been proposed by its author. ${ }^{15}$

The authors of the Purdue study concurred with Rider that exponential library growth cannot continue indefinitely:

Even though collections, acquisitions, expenditures, etc. which are ten, twenty, or fifty times the present levels cannot be seriously proposed for the foreseeable future and although some of the fitted curves, when extended some years beyond 1980 , indicate inconceivably high levels, there is little basis for expecting an early deceleration in library growth. In short, the records of growth since 1951, including the most recent years, and the unfaltering growth of even the largest libraries, indicate that this growth will not soon decelerate. ${ }^{16}$

The authors speculated that if deceleration in the rate of library growth does occur, "it can hardly be expected before 1980 and perhaps not for many years thereafter."17 However, in a recent issue of the Purdue study, which examined library growth through 1969
70 with a follow-up stage beginning in that year, the authors qualified their earlier prediction to read as follows:

Collections, acquisitions, expenditures, etc., which are ten, twenty, or fifty times the present levels cannot be seriously envisioned for the foreseeable future and some of the fitted curves, when extended some years beyond 1980 , indicate inconceivably high levels, thus there is some basis for expecting some deceleration of library growth. Although there has been con- uous growth since 1951, including he of the most recent years, library fowth currently is faltering. ${ }^{18}$

The above conclusion is supported by the results of the study that is reported in the following section of this paper.

\section{REPORT OF THE STUDY}

The twenty-five largest ARL libraries as ranked on the basis of collection size by the 1973-74 ARL statistics are listed in Table 3. Within this group of libraries nine private and sixteen public institutions are represented. The data for the study were compiled from ARL statistics for 1962-63 through 1973-74. After being corrected for transcription and keypunching errors, the data were used in a PL-1 computer program written expressly for the study. No attempt was made to resolve inconsistencies in the data which were caused either by reporting discrepancies or errors as it was presumed that such inconsistencies would affect the results of the study only minimally.

The time period examined was selected on the basis of the following rationale:

(1) The twelve years from 1962-63 through 1973-74 were perceived to have encompassed a unique phase in the post-World War II development of university libraries. The year 1962-63 was selected as the beginning point for the study because it marked the first full year of recovery from the minor eco- 
TABLE 3

Rank by Collection Stze (Mmlions of Volumes), 1962-63 AND 1973-74

\begin{tabular}{lcll}
\hline \hline \multicolumn{1}{c}{ Library } & $\begin{array}{c}\text { Collection Size } \\
1962-63\end{array}$ & \multicolumn{1}{c}{ Library } & $\begin{array}{c}\text { Collection Size } \\
1973-74\end{array}$ \\
\hline 1. Harvard & 7.074 & 1. Harvard & 9.028 \\
2. Yale & 4.693 & 2. Yale & 6.351 \\
3. Ilinois & 3.635 & 3. Illinois & 5.328 \\
4. Michigan & 3.134 & 4. Columbia & 4.573 \\
5. Columbia & 3.088 & 5. Michigan & 4.549 \\
6. Berkeley & 2.829 & 6. Berkeley & 4.477 \\
7. Cornell & 2.413 & 7. Toronto & 4.212 \\
8. Stanford & 2.379 & 8. Cornell & 4.158 \\
9. Chicago & 2.271 & 9. Stanford & 3.982 \\
10. Minnesota & 2.221 & 10. Indiana & 3.665 \\
11. Toronto & 1.944 & 11. Texas & 3.485 \\
12. UCLA & 1.867 & 12. Chicago & 3.479 \\
13. Pennsylvania & 1.836 & 13. Minnesota & 3.395 \\
14. Princeton & 1.834 & 14. UCLA & 2.912 \\
15. Indiana & 1.787 & 15. Ohio State & 2.785 \\
16. Duke & 1.593 & 16. Wisconsin & 2.615 \\
17. Ohio State & 1.591 & 17. Princeton & 2.557 \\
18. Northwestern & 1.587 & 18. Pennsylvania & 2.530 \\
19. Texas & 1.578 & 19. Duke & 2.390 \\
20. Wisconsin & 1.446 & 20. New York University & 2.349 \\
21. North Carolina & 1.350 & 21. Northwestern & 2.102 \\
23. Washington, Seattle & 1.267 & 22. Washington, Seattle & 2.083 \\
24. Johns Hopkins & 1.263 & 23. Michigan State & 2.044 \\
25. New York University & 1.223 & 24. North Carolina & 2.006 \\
37. Michigan State & .960 & 25. Johns Hopkins & \\
\hline
\end{tabular}

nomic recession of 1960-61. There is little need to inventory in detail those events and economic conditions which affected library growth during these twelve years, e.g., the infusion and subsequent withdrawal of federal funds for library development; the accelerated expansion and subsequent retrenchment of academic programs; numerous library construction projects; and, more recently, an economic recession characterized by double-digit inflation. Brevity necessitates that a fuller justification of this perception be omitted, and for that reason the reader is referred to the McAnally and Downs article "The Changing Role of Directors of University Libraries." 19 Their article is cited because a similar perception seems to underlie the authors' review of events in the 1960s, germane to the development of university libraries, and their examination of those events in relation to the problems confronting university libraries in the 1970s.

(2) In the Economics of Academic Libraries, Baumol and Marcus noted that "the 1950 s and sixties were a period during which colleges and universities [and by extension, their libraries] were comparatively well supplied with financial resources" but "the recent financial crisis of higher education is not reflected in the trends reported" in their analysis of recent library growth, based upon data from the Purdue study..$^{20}$ However, the effects of this recent financial crisis should be reflected in the trends reported in an analysis of library growth from 1962-63 through 1973-74.

As was noted in the introduction, one purpose of this study was to determine if the rates of growth sustained by the twenty-five largest ARL libraries from 1962-63 through 1973-74 corroborate the rate of library growth specified by 
the Rider hypothesis. To this end, tables which report the growth-related measurements obtained for these libraries were prepared. Before proceeding, two of the tables require some explanation.

Table 4: For each library the years required for the 1962-63 collection to double in size were projected on the basis of the annual mean rate of growth for 1962-63 through 1973-74. For certain libraries the wide range in yearly percentage changes in collection size can be attributed either to adjustments posted because of previous reporting errors, to the initial inclusion or exclusion of the holdings of a satellite library, or simply to a significant increase or decrease in the volume of acquisitions for one year.

Table 5: For each size level a volume range was defined, e.g., for the 2 million-volume level the range was 1.9 to 2.39 million volumes; for the 2.5 mil- lion-volume level, 2.4 to 2.89 million volumes; and so forth. The "pre-" mean rate of growth represents the annual mean rate of growth posted from 196263 through the year when the collection reached the specified size level, provided that there were at least two years of growth to be measured. Similarly, the "post-" mean represents the mean rate of growth registered from the year when the collection attained the specified size level through 1973-74, again provided that there were at least two years of growth to be measured. To illustrate, Texas in 1966-67 reported holdings of 1.945 million volumes; therefore the "pre-" mean is the annual mean rate of growth from 1962-63 through 1966-67 (four years) while the "post-" mean is the annual mean rate of growth from 1966-67 through 1973-74 (seven years).

In order for a library to double in

TABLE 4

Rank by Annual Mean Rate of Growth and Doubling Period with Range of Yearly Percentage Changes in Collection Size (1962-63 to 1973-74)

\begin{tabular}{lccc}
\hline \hline \multicolumn{1}{c}{ Library } & Mean Rate of Growth & Doubling Period & Range ( \pm ) \\
\hline 1. Texas & $7.67 \%$ & 10 yrs. & $4.34 / 21.80 \%$ \\
2. Toronto & 7.39 & 10 & $-4.70 / 13.67$ \\
3. Michigan St. & 7.31 & 10 & $2.42 / 9.52$ \\
4. Indiana & 7.01 & 11 & $-7.48 / 22.56$ \\
5. N.Y.U. & 6.51 & 12 & $-6.99 / 22.45$ \\
6. Wisconsin & 6.34 & 12 & $-8.05 / 22.16$ \\
7. Ohio St. & 5.65 & 13 & $4.35 / 7.75$ \\
8. UCLA & 5.60 & 13 & $3.39 / 9.49$ \\
9. Cornell & 5.08 & 15 & $2.86 / 6.79$ \\
10. Stanford & 4.83 & 15 & $1.57 / 11.92$ \\
11. Washington & 4.71 & 16 & $3.27 / 5.87$ \\
12. Johns Hopkins & 4.36 & 17 & $-2.60 / 9.25$ \\
13. Duke & 4.30 & 17 & $3.52 / 4.84$ \\
14. Berkeley & 4.26 & 17 & $2.14 / 5.78$ \\
15. Minnesota & 4.17 & 17 & $3.18 / 5.69$ \\
16. North Carolina & 4.17 & 18 & $-9.64 / 24.15$ \\
17. Chicago & 3.97 & 18 & $2.75 / 5.19$ \\
18. Northwestern & 3.73 & 20 & $-6.18 / 14.74$ \\
19. Columbia & 3.67 & 20 & $.96 / 11.79$ \\
20. Illinois & 3.55 & 20 & $-1.00 / 5.61$ \\
21. Princeton & 3.49 & 21 & $-9.25 / 16.84$ \\
22. Michigan & 3.46 & 21 & $.24 / 5.77$ \\
23. Pennsylvania & 3.07 & 23 & $-1.07 / 4.32$ \\
24. Yale & 2.79 & 26 & $.21 / 3.59$ \\
25. Harvard & 2.25 & 32 & $1.65 / 3.04$ \\
\hline
\end{tabular}


TABLE 5

Mean Rates of Collection Growth (1962-63 to 1973-74) Contrasted to Mean Rates of Growth at Various Levels of Collection Size

\begin{tabular}{|c|c|c|c|c|c|c|c|c|c|c|c|}
\hline \multirow[b]{2}{*}{ Library } & \multirow{2}{*}{$\begin{array}{c}\text { Mean Growth } \\
\text { Rate } \\
\text { (12 yrs.) }\end{array}$} & \multicolumn{2}{|c|}{ 2.0 Million Vol. } & \multicolumn{2}{|c|}{ 2.5 Million Vol. } & \multicolumn{2}{|c|}{ 3.0 Million Vol. } & \multicolumn{2}{|c|}{ 3.5 Million Vol. } & \multicolumn{2}{|c|}{ 4.0 Million Vol. } \\
\hline & & $\begin{array}{l}\text { Pre-2.0 } \\
\text { Mean }\end{array}$ & $\begin{array}{l}\text { Post-2.0 } \\
\text { Mean }\end{array}$ & $\begin{array}{c}\text { Pre-2.5 } \\
\text { Mean }\end{array}$ & $\begin{array}{l}\text { Post-2.5 } \\
\text { Mean }\end{array}$ & $\begin{array}{c}\text { Pre-3.0 } \\
\text { Mean }\end{array}$ & $\begin{array}{l}\text { Post-3.0 } \\
\text { Mean }\end{array}$ & $\begin{array}{c}\text { Pre-3.5 } \\
\text { Mean }\end{array}$ & $\begin{array}{l}\text { Post-3.5 } \\
\text { Mean }\end{array}$ & $\begin{array}{c}\text { Pre-4.0 } \\
\text { Mean }\end{array}$ & $\begin{array}{l}\text { Post-4.0 } \\
\text { Mean }\end{array}$ \\
\hline 1. Texas & $7.67 \%$ & $5.37 \%$ & $8.98 \%$ & $5.53 \%$ & $13.37 \%$ & & & & & & \\
\hline 2. Toronto & 7.39 & $\ldots$ & ... & 7.71 & 7.21 & $8.41 \%$ & $6.55 \%$ & $9.52 \%$ & $3.67 \%$ & & \\
\hline 3. Michigan St. ${ }^{\circ}$ & 7.31 & & & & & & & & & & \\
\hline 4. Indiana & 7.01 & $\begin{array}{r}3.12 \\
1088\end{array}$ & $\begin{array}{l}8.47 \\
9.87\end{array}$ & 5.87 & 8.37 & 7.34 & 6.14 & & & & \\
\hline $\begin{array}{l}\text { 5. N.Y.U. } \\
\text { 6. Wisconsin }\end{array}$ & $\begin{array}{l}6.51 \\
6.34\end{array}$ & $\begin{array}{r}10.88 \\
7.27\end{array}$ & $\begin{array}{l}2.87 \\
5.57\end{array}$ & 6.91 & 4.83 & & & & & & \\
\hline 7. Ohio St. & 5.65 & 5.73 & 5.61 & 6.02 & 4.66 & & & & & & \\
\hline 8. UCLA & 5.60 & 7.51 & 5.41 & 7.26 & 4.66 & 6.59 & 3.87 & & & & \\
\hline 9. Cornell & 5.08 & $\ldots$ & $\ldots$ & $\ldots$ & $\ldots$ & 6.15 & 4.45 & 6.11 & 3.84 & & \\
\hline $\begin{array}{l}\text { 10. Stanford } \\
\text { 11. Washington }\end{array}$ & 4.83 & & & $\ldots$ & $\ldots$ & 5.52 & 4.43 & 5.49 & 3.67 & & \\
\hline $\begin{array}{l}\text { 11. Washington } \\
\text { 12. Johns Hopkins }\end{array}$ & $\begin{array}{l}4.71 \\
4.36\end{array}$ & $\begin{array}{l}4.84 \\
6.68\end{array}$ & $\begin{array}{l}4.14 \\
2.93\end{array}$ & & & & & & & & \\
\hline 13. Duke & $\begin{array}{l}4.30 \\
4.30\end{array}$ & $\begin{array}{l}0.00 \\
4.07\end{array}$ & 4.49 & & & & & & & & \\
\hline 14. Berkeley & 4.26 & $\ldots$ & $\ldots$ & & & & & 4.23 & 4.29 & & \\
\hline 15. Minnesota & 4.17 & $\cdots$ & $\cdots$ & 3.75 & 4.33 & 4.12 & 4.26 & & & & \\
\hline $\begin{array}{l}\text { 16. North Carolina } \\
\text { 17. Chicago }\end{array}$ & $\begin{array}{l}4.17 \\
3.97\end{array}$ & & & 2.92 & 4.20 & 3.94 & 4.02 & & & & \\
\hline 18. Northwestern & 3.73 & 3.89 & 3.54 & & & & & & & & \\
\hline 19. Columbia & 3.67 & $\ldots$ & $\ldots$ & $\ldots$ & $\ldots$ & $\ldots$ & $\ldots$ & & & $4.52 \%$ & $2.61 \%$ \\
\hline 20. Illinois & 3.55 & & & & & $\ldots$ & & $\ldots$ & & 3.97 & 3.40 \\
\hline 21. Princeton & 3.49 & 4.92 & 3.17 & 3.35 & 4.11 & & & & & & \\
\hline 22. Michigan & 3.46 & & & & & $\cdots$ & $\cdots$ & 4.33 & 3.26 & 4.20 & 2.56 \\
\hline $\begin{array}{l}\text { 23. Pennsylvania } \\
\text { 24. Yale }{ }^{\dagger}\end{array}$ & $\begin{array}{l}3.07 \\
2.79\end{array}$ & 2.21 & 3.39 & 3.09 & 2.99 & & & & & & \\
\hline 25. Harvard $t$ & 2.25 & & & & & & & & & & \\
\hline
\end{tabular}


size every sixteen years, it must maintain an annual mean rate of growth of approximately 4.5 percent. As shown in Table 4, sixteen of the twenty-five libraries posted annual mean rates of growth of from 4.17 to 7.67 percent. On the one hand, the wide range of the growth rates imposes some restrictions upon the use of the Purdue growth-rate figures to forecast collection growth for individual libraries. To elaborate, if the mean rate of growth maintained in recent years by an individual library does not correspond closely to the appropriate Purdue figure, then for that library the utility of the composite figure as a predictive tool is diminished-unless, of course, the composite figure is cited as the rate of growth that should be maintained in the future.

The composite figure is not a standard which denotes the rate of collection growth that ought to be sustained but instead is a measure of growth computed from the growth rates experienced by $X$-number of libraries for $N$-number of years. The authors of the Purdue study also noted this limitation when they acknowledged that their analyses of library growth "may be regarded as suggestive of events within individual libraries, although the course of growth for the individual library is rarely as regular as that of a group."21 On the other hand, the growth rates listed in Table 4 seemingly substantiate the accuracy of the Rider hypothesis in predicting library growth, but a closer examination of these and other growth measurements presented in the tables reveals the limitations of the hypothesis' usefulness.
By juxtaposing Tables 3 and 4, it becomes apparent that the ranking by annual mean rate of growth is an imprecise inversion of the ranking by collection size for 1962-63. A matrix (Table 6 ) showing the distribution of libraries by rank of collection size and mean rate of growth illustrates this point.

TABLE 6

Distribution of Libraries: Collection Size and Growth Rates

\begin{tabular}{cccccc}
\hline \hline $\begin{array}{c}\text { Rank by Collection Growth } \\
\text { Size (1962-63) } \\
\text { 1-5 }\end{array}$ & $\begin{array}{c}\text { Rank Annual Mean Rate of } \\
\text { 6-10 }\end{array}$ & $\begin{array}{c}\text { 11-15rough } \\
1973-74)\end{array}$ & $16-20$ & $21-25$ \\
\hline $1-5$ & - & $\overline{2}$ & $\overline{2}$ & 2 & 3 \\
$6-10$ & $\overline{2}$ & 2 & 2 & 1 & $\overline{2}$ \\
$11-15$ & 1 & $\overline{1}$ & $\overline{1}$ & 2 \\
$16-20$ & 1 & 2 & 1 & 1 & - \\
$21-25$ & 2 & - & 2 & 1 & - \\
\hline
\end{tabular}

Although Toronto is an obvious exception to the above generalization, its anomalous position in the ranking by mean rate of growth can be attributed to a decision made by the Ontario government early in the 1960 s to upgrade the quality of graduate education at the university; consequently the library sustained a high rate of growth from 1963 through $1970 .^{22}$

Of course, other exceptions can be discerned, e.g., Princeton and Pennsylvania, and undoubtedly their anomalous positions in the ranking by growth rate also could be explained. Nonetheless, these exceptions do not invalidate the observation that the ranking by mean rate of growth is an imprecise inversion of the ranking by collection size-an observation also supported by another matrix (Table 7), which shows the distribution of libraries by mean rate of

TABLE 7

Distribution of Libraries: Growth Rates and Collection Stze

\begin{tabular}{|c|c|c|c|c|c|}
\hline $\begin{array}{l}\text { Mean Rate of Growth } \\
\text { (1962-63 to } 1973-74)\end{array}$ & $<1-1.49^{\text {Ran }}$ & $\begin{array}{l}\text { Collection Siz } \\
\text { 1.5-1.99 }\end{array}$ & $\begin{array}{l}32-63,{ }^{M} \\
2-2.49\end{array}$ & $\begin{array}{l}\text { Volumes ) } \\
2.5-2.99\end{array}$ & $\geqq 3$ \\
\hline $\begin{array}{l}<4 \text { percent } \\
\geqq 4 \text { percent }\end{array}$ & $\overline{7}$ & $\begin{array}{l}3 \\
5\end{array}$ & $\frac{1}{3}$ & $\overline{1}$ & 5 \\
\hline
\end{tabular}


growth and collection size.

Of the sixteen libraries which had annual mean rates of growth greater than 4 percent, fifteen had collections in 1962-63 of less than 2.5 million volumes, whereas the five largest libraries had mean rates of growth of less than 4 percent.

The comparisons detailed in Table 5 more precisely show that the rate of collection growth is an inverse function of collection size. Note that (1) at the 2 million-volume level, eight of the twelve libraries registered higher mean rates of growth prior to reaching that size level; (2) at the 2.5 million-volume level, five of the ten libraries; (3) at the 3 million-volume level, five of the seven libraries; (4) at the 3.5 million-volume level, four of the five libraries; and (5) at the 4 million-volume level, all three of the libraries posted higher mean rates of growth prior to reaching that size level.

It is not asserted, however, that as higher levels of collection size are approached, a deceleration in the rate of growth will be immediately realized, for as was demonstrated by Toronto during the 1960s, the deceleration effect can be countered provided the requisite financial resources are available and, equally important, the commitment is made to maintain or accelerate the rate of collection growth. What is asserted, however, is that as higher levels of collection size are approached, it becomes increasingly likely that the rate of collection growth will begin to decelerate. Indeed, the comparisons reported in Table 5 indicate that the size level of 3 million volumes is the threshold beyond which a deceleration in the rate of collection growth can be expected. Admittedly, at the 2 and 2.5 million-volume levels most of the libraries did post higher mean rates of growth prior to reaching either or both of those size levels, but it was at the 3 million-volume level where the trend towards decelera- tion in the rate of collection growth became more prevalent.

There are exceptions to the above generalization-specifically, Chicago and Cornell at the 3 million-volume level and Berkeley at the 3.5 million-volume level-but these exceptions are consistent with the previous acknowledgment that the inverse relationship between the rate of collection growth and collection size can be suspended. That the effect of this collection-size-threshold on library growth was not reflected in the composite growth-rate figure derived for the "large" libraries in the 1965 Purdue study can be explained. In 1950-51, of the fourteen "large" ARL libraries only Harvard and Yale reported holdings of more than 3 million volumes, and by 1963-64, only Illinois, Columbia, and Michigan had joined Harvard and Yale in reporting holdings of 3 million or more volumes; hence the deceleration effect of the size-threshold on the rate of library growth as represented by the Purdue figure for the "large" libraries would have been minimal.

Taking the eleven libraries which appeared in Rider's and in this study, Table 8 was prepared in order to compare by sixteen-year intervals from 1938 through 1970 those libraries' projected to their reported collection sizes. ${ }^{23}$ Of the eleven libraries, only North Carolina and Illinois either matched or exceeded their respective collection size projections for 1954 and 1970. Note, however, that the reduced percentage by which Illinois exceeded its 1970 projection and that its recent annual mean rate of growth indicate that at least since 1954 Illinois began to experience a deceleration in its rate of growth. The comparisons certainly do not substantiate Rider's hypothesis about future library growth. With specific reference to Harvard and Yale, the comparisons either should uphold or refute the contention that there exists a collection-size-threshold, for in 1938 Harvard's collection 
TABLE 8

Projected and Actual Collection Stzes of Eleven Librarues (1954 and 1970) INCLUDED IN RIDER's STUdy (MILLIONS OF Volumes)

\begin{tabular}{lccccccc}
\hline \hline \multicolumn{1}{c}{ Library } & $\begin{array}{c}1938 \\
\text { Actual }\end{array}$ & $\begin{array}{c}1954 \\
\text { Projected }\end{array}$ & $\begin{array}{c}1954 \\
\text { Actual }\end{array}$ & $\begin{array}{c}1954 \\
\text { Difference }\end{array}$ & $\begin{array}{c}1970 \\
\text { Projected }\end{array}$ & $\begin{array}{c}1970 \\
\text { Actual }\end{array}$ & $\begin{array}{c}1970 \\
\text { Difference }\end{array}$ \\
\hline Harvard & 3.941 & 7.883 & 5.833 & $-26 \%$ & 15.765 & 8.278 & $-47 \%$ \\
Yale & 2.748 & 5.496 & 4.246 & -23 & 10.992 & 5.646 & -49 \\
Columbia & 1.615 & 5.230 & 2.070 & -36 & 6.460 & 4.092 & -37 \\
Princeton & .919 & 1.839 & 1.276 & -31 & 3.678 & 2.194 & -40 \\
Pennsylvania & .882 & 1.764 & 1.371 & -22 & 3.527 & 2.267 & -36 \\
North Carolina & .358 & .715 & .663 & -7 & 1.430 & 1.723 & +20 \\
Illinois & 1.130 & 2.260 & 2.790 & +23 & 4.520 & 4.611 & +2 \\
Cornell & 1.035 & 2.070 & 1.675 & -19 & 4.141 & 3.606 & -13 \\
Minnesota & 1.018 & 2.035 & 1.764 & -13 & 4.071 & 2.945 & -28 \\
Berkeley & 1.142 & 2.283 & 1.987 & -13 & 4.566 & 3.845 & -16 \\
Chicago & 1.233 & 2.465 & 1.900 & -23 & 4.931 & 2.978 & -40 \\
\hline
\end{tabular}

surpassed and Yale's collection approached the 3 million-volume size level. Through 1938, Rider reported that both libraries had doubled in size every sixteen years, but the comparisons reveal a marked deceleration after 1938 in Harvard's and Yale's respective growth rates.

\section{Conclusion}

The preceding analysis has attempted:

1. To demonstrate that the Rider hypothesis cannot be used reliably to project library growth. Rider used the hypothesis to extrapolate future levels of library growth in order to dramatize the seriousness of the impending growth problem. Library growth realized since the conclusion of World War II has confirmed the correctness of Rider's perception while simultaneously it has not substantiated the accuracy of the hypothesis as a predictive tool.

2. To identify a collection-size-threshold of approximately three million volumes beyond which an individual library can anticipate a deceleration in its rate of collection growth. However, it must be reiterated that the deceleration effect of this size-threshold can be suspended as was demonstrated by
Toronto during the 1960 s and by Illinois through the 1950s.

3. To point out the limitations of the Purdue study growth projections when used by an individual university library to forecast collection growth-particularly as its collection approaches the 3 million-volume size level.

Although this paper has questioned the accuracy of Rider's hypothesis as a predictive tool, it has not questioned the validity of Rider's fundamental perception that library growth would become an increasingly perplexing problem for university libraries. Table 9 illustrates the scope of this problem for the twenty-five libraries in this study. The range in actual volume increases in collection size was .694 to 2.268 million volumes; note also that in certain instances the corresponding percentage increases belie the size of the actual volume increases. A review of the annual reports issued from fiscal year 1963 through fiscal year 1973 by ten of the libraries in the study confirms the correctness of Rider's perception, for during this period each of the ten libraries cited in its annual reports the existence of problems engendered by the growth of its collection and the resultant need for more building space to accommodate an expanding collection as well as staff. ${ }^{24}$ 
TABLE 9

RANK BY: Volume INCRease IN Collection Stze (1962-63 to 1973-74) and Percentage Increase in Collection Size (1962-63 to 1973-74)

\begin{tabular}{|c|c|c|c|}
\hline Library & $\begin{array}{l}\text { Volume Increase } \\
\text { (Millions of Volumes) }\end{array}$ & Library & $\begin{array}{c}\text { Percentage } \\
\text { Increase }\end{array}$ \\
\hline 1. Toronto & 2.268 & 1. Texas & $122.91 \%$ \\
\hline 2. Harvard & 1.954 & 2. Michigan St. & 116.86 \\
\hline 3. Texas & 1.940 & 3. Toronto & 116.63 \\
\hline 4. Indiana & 1.878 & 4. Indiana & 105.07 \\
\hline 5. Cornell & 1.745 & 5. N.Y.U. & 95.49 \\
\hline 6. Illinois & 1.694 & 6. Wisconsin & 92.65 \\
\hline 7. Berkeley & 1.650 & 7. Ohio St. & 82.98 \\
\hline 8. Stanford & 1.603 & 8. UCLA & 81.89 \\
\hline 9. UCLA & 1.529 & 9. Cornell & 72.29 \\
\hline 10. Columbia & 1.484 & 10. Stanford & 67.38 \\
\hline 11. Yale & 1.458 & 11. Washington & 65.90 \\
\hline 12. Michigan & 1.415 & 12. Johns Hopkins & 58.90 \\
\hline 13. Wisconsin & 1.339 & 13. Duke & 58.86 \\
\hline 14. Ohio St. & 1.320 & 14. Berkeley & 58.23 \\
\hline 15. Minnesota & 1.258 & 15. Minnesota & 56.66 \\
\hline 16. Chicago & 1.214 & 16. Chicago & 53.43 \\
\hline 17. N.Y.U. & 1.168 & 17. North Carolina & 51.43 \\
\hline 18. Michigan St. & 1.112 & 18. Columbia & 48.06 \\
\hline 19. Duke & .937 & 19. Northwestern & 48.02 \\
\hline 20. Washington & .835 & 20. Illinois & 46.60 \\
\hline 21. Princeton & .781 & 21. Michigan & 45.16 \\
\hline 22. Northwestern & .762 & 22. Princeton & 42.60 \\
\hline 23. Johns Hopkins & .744 & 23. Pennsylvania & 39.30 \\
\hline 24. Pennsylvania & .721 & 24. Yale & 35.32 \\
\hline 25. North Carolina & .694 & 25. Harvard & 27.63 \\
\hline
\end{tabular}

Furthermore, during this period each of these ten libraries either was planning for or was in the midst of overseeing the construction of new library facilities.

University libraries long have been acutely aware of the problem of ex- ponential library growth, which was articulated over thirty years ago by Fremont Rider. It is not anticipated that this problem will soon ameliorate, and certainly it is not the intent of this paper to minimize the extent and the prevalence of this problem.

\section{REFERENCES}

1. Fremont Rider, The Scholar and the Future of the Research Library (New York: Hadham Pr., 1944); O. C. Dunn, W. F. Seibert, and Janice A. Scheuneman, The Past and Likely Future of 58 Research Libraries, 1951-1980; A Statistical Study of Growth and Change (Lafayette, Ind.: Purdue University, 1965).

2. Rider, The Scholar and the Future of the Research Library, p.3.

3. Ibid., p.9.

4. Ibid., p.9-12.

5. Keyes D. Metcalf, "The Promise of Microprint," College \& Research Libraries 6: 170 (March 1945).

6. Rider, The Scholar and the Future of the Research Library, p.16-17.
7. Ibid., p.14-19.

8. Metcalf, "The Promise of Microprint," p.170.

9. Fremont Rider, "Author's Statement: Fremont Rider," College \& Research Libraries 6:181 (March 1945).

10. Rider, The Scholar and the Future of the Research Library, p.12.

11. H. William Axford, "Rider Revisited," College \& Research Libraries 23:345-47 (July 1962); George Piternick, "Library Growth and Academic Quality," College \& Research Libraries 24:223-29 (May 1963).

12. Dunn, Past and Likely Future, 1965, p.21, $37,40,43,46$. The twenty-five libraries included in the present study were assigned in the Purdue study to the following size 
categories: "large" libraries-Harvard, Yale, Illinois, Columbia, Michigan, Berkeley, Cornell, Stanford, Indiana, Chicago, Minnesota, Princeton, UCLA, and Pennsylvania; "medium-large" libraries-Duke, Johns Hopkins, New York University, North Carolina, Northwestern, Ohio State, Texas, Washington, and Wisconsin; "medium-small" libraries-Michigan State. Toronto was not included in the Purdue study.

13. Guy Garrison, review of O. C. Dunn, The Past and Likely Future of 58 Research $\mathrm{Li}$ braries, in Library Quarterly 36:170 (1966).

14. Robert L. Talmadge, review of O. C. Dunn, The Past and Likely Future of 58 Research Libraries, in College \& Research Libraries 27:319 (July 1966).

15. Dunn, Past and Likely Future, 1965, p.1.

16. Ibid., p. 20 .

17. Ibid., p.76.

18. O. C. Dunn, Don L. Tolliver, and Miriam A. Drake, The Past and Likely Future of 58 Research Libraries, 1950-1980: A
Statistical Study of Growth and Change, 1971-72 (9th issue; Lafayette, Ind.: Purdue University, 1973), p.12. (ERIC microfiche ED 082780)

19. Arthur M. McAnally and Robert B. Downs, "The Changing Role of Directors of University Libraries," College \& Research Libraries 34:103-25 (March 1973).

20. William J. Baumol and Matityahu Marcus, Economics of Academic Libraries (Washington, D.C.: American Council on Education, 1973), p.1.

21. Dunn, Past and Likely Future, 1965, p.75.

22. Toronto University Library, Annual Report 1962-63 (Toronto: 1963), p.2.

23. "College and University Library Statistics, 1953-54," College \& Research Libraries 16:37-53 (Jan. 1955). The 1938 figures were reported by Rider in his study. The 1954 figures were reported in the above cited article. The 1970 figures were reported in the 1969-70 ARL statistics.

24. The ten libraries are Harvard, Yale, Illinois, Michigan, Toronto, Cornell, Stanford, Minnesota, UCLA, and Ohio State. 